\title{
PENINGKATAN KEMAMPUAN PEDAGOGIK DIGITAL PENDIDIK MELALUI PDCA DALAM MGMP MASA COVID-19
}

\section{UTILIZATION OF TEACHERS' DIGITAL PEDAGOGIC COMPETENCIES THROUGH PDCA IN MGMP DURING THE COVID-19}

\author{
PARIMPUNAN
}

SMP Negeri 91 Jakarta

$\begin{array}{ll}\text { Received: } & \text { May 07, } 2021 \\ \text { Revised: } & \text { May 10,2021 } \\ \text { Accepted: } & \text { May 17, } 2021\end{array}$

\begin{abstract}
The lack of mastery teachers' digital pedagogical competences which has an impact to tasks, functions. This research 4 months, February to April 2020-2021, 5 subject groups 3 cycles, 3 meetings and 4 activities for: Planning, Action, Observation and Reflection. Uniqueness of educators, is reflected in cycle I, digital identification of real teacher, cycle II to III, in results in cycle I to II have increased $8 \%$, cycle II to III has increased $8 \%$ so cycle III to I has increased $16 \%$. Completeness increased from cycle I to II $8 \%$ and cycle II to III $36 \%$ so that cycle III to I was $44 \%$. Judging remedial cycle I to II increased $17 \%$ and cycle II to III increased $3 \%$ so that cycle I to III 20\%. The results of this indicate that the teacher's, can improve the digital pedagogical competence, relevant research to improve effectiveness of quality control
\end{abstract}

\begin{abstract}
Abstrak. Kurangnya penguasaan kemampuan pedagogik digital pendidik LMP yang berdampak pada kemampuannya apabila melaksanakan tugasnya. Penelitian ini bertujuan meningkatkan hasil kemampuan pedagogik digital pendidik melalui Strategi PDCA (Plan, Do, Check). Penelitian ini dilaksanakan 4 bulan mulai Februari sampai April minggu ketiga tahun pelajaran 20202021. Subjek penelitian 5 kelompok mata pelajaran (LMP) dan dilaksanakan 3 siklus, dengan 3 pertemuan 4 kegiatan tiap siklus yaitu: perencanaan, tindakan, observasi dan refleksi. Siklus 1 berupa Keunikan pendidik dalam menjalankan profesinya sesuai tupoksi kemampuan digital pendidik, siklus I direfleksi untuk merencanakan tindakan siklus II. Selanjutnya siklus II merupakan inovasi, kendala, dan penomena keunikan digital realita pendidik secara riil serta informasi MGMP yang dilakukan di satuan pendidikan, siklus II direfleksi untuk merencanakan siklus III. Berikutya siklus III berupa PDG oleh kepala satuan pendidikan dalam kegiatan MGMP satuan pendidikan. Hasil PDG siklus I terhadap siklus II ada kenaikan sebesar 8\%, siklus II terhadap siklus III terdapat kenaikan sebesar 8\% jadi siklus III terhadap siklus I ada kenaikan sebesar 16\%. Ketuntasan kemampuan meningkat dari siklus I ke siklus II sebesar 8\% dan siklus II ke siklus III sebesar 36\% sehingga siklus III terhadap siklus I sebesar 44\%. Ditinjau dari hasil remedial, ketuntasan sebagai dampak konpetensi digital pendidik dari siklus I ke siklus II ternyata naik sebesar $17 \%$ dan siklus II ke siklus III naik sebesar 3\% sehingga siklus I ke siklus III naik sebesar 20\%. Hasil ini menunjukkan bahwa PDG pendidik LMP MGMP Satuan pendidikan melalui strategi PDCA, dapat meningkatkan kemampuan pendidik, penelitian relevan meningkatkan efektifitas pengendalian mutu Kemampuan pedagogik digital, MGMP, PDCA
\end{abstract}

Keywords: Digital pedagogical competence, MGMP, PDCA

Kata kunci:

$\left(^{\star}\right)$ Corresponding Author: parimpunan99@yahoo.com

How to Cite: Parimpunan. (2021). Peningkatan Kemampuan Pedagogik Digital Pendidik Melalui PDCA Dalam MGMP Masa Covid-19. Jurnal Lingkar Mutu Pendidikan, 18 (1), 81-90. https://doi.org/10.54124/jlmp.v18i1.10

\section{PENDAHULUAN}

Tahun 2020 hampir semua negara di dunia dilanda wabah Covid-19, dan Indonesia menjadi salah satu negara terdampak covid dan kasusnya terus meningkat dalam beberapa bulan terakhir. Oleh karena itu perlu adaftif pembelajaran agar proses belajar mengajar tetap berlangsung tidak terhalangi melalui tanpa tatap muka, senjatanya adalah paedagogik dan digitalisasi.

Pemanfaatan Teknologi dan Informasi (TIK) dalam pembelajaran masih belum optimal digunakan pendidik-pendidik. Umumnya pendidik baru sebatas penggunaan media seperti power point, internet, dan ebook. Padahal kondisi saat ini idealnya telah merubah aliran pendidikan, tidak hanya transfer knowladge saja tetapi lebih ke transfer of values. Pembelajaran harus berorientasi pada mewujudkan 
lingkungan yang memungkinkan peserta didik untuk memecahkan hambatan, berimajinasi, berinovasi, menciptakan, dan berkolaborasi mengembangkan ekosistem 4.0. Dapat memacu konektivitas manusia yang lebih luas dilingkungan global dengan tetap menyatukan nilai-nilai spiritual, etika, moralitas, identitas nasional dan rasa empati pada masyarakat, melalui penyampaian kurikulum dan transfer teknologi dengan memperhatikan makna serta risiko yang ditimbulkan oleh revolusi Industri 4.0 (Hussin 2018).

Kesenjangan antara pendidik dan peserta didik dalam pemanfaatan teknologi menjadi tantangan yang perlu segera diatasi. Anak-anak tumbuh di era digital yang deras dengan inforamsi., serta mereka hidup tidak lepas dari teknologi. Wacana digital native makin banyak digunakan dalam berbagai kajian dan literatur. Pertimbangan digital native banyak digunakan dalam berbagai litelatur. Adanya juga pertimbangan mengenai network generation, generasi Y, generasi Z, millenials. Echenique, cyberg dkk, mengatakan bahwa peserta didik sekarang sebagai digital learners, hal ini karena mereka sangat dipengaruhi oleh teknologi informasi sampai-sampai kita harus menganggap mereka sebagai "digital" (Strijbos 2015).

Penelitian ini bermaksud untuk menilik secara konseptual dan faktual mengenai digital pedagogy sebagai alternatif solusi dalam pembelajaran masa digital. Masyarakat belajar dengan bantuan teknologi baru, bermain video game yang kompleks, simulasi yang menantang, kursus online, jejaring sosial dan pembelajaran online.

Pengalihan proses pembelajaran jarak jauh berdasarkan hasil penelitian dalam merespon kemampuan pedagogik digital. Ternyata adanya kekurangan informasi terkait pendekatan pedagogik dan prinsip yang diambil terhadap banyaknya perubahan ke pendidikan digital dan mempunyai peluang untuk memungkinkan lebih fleksibel dan inovatif dengan metode digital dari pendidikan (Crowford 2020). .

Situasi kondisi pandemi mempengaruhi sistem pendidikan maka dalam ilmu manajemen terdapat konsep pemecahan masalah yang dapat diterapkan di lingkungan pendidikan Covid-19, yaitu menggunakan pendekatan PDCA sebagai proses pemecahan masalah. Dalam bahasa kendali mutu, pemecahan masalah dan proses kendali dengan pola yang konsisten dan sistematis disebut dengan PDCA.

Salah satu wadah dalam rangka meningkatkan kemampuan pedagogik digital pendidik dalam pelaksanaan proses pembelajaran adalah Musyawarah Pendidik Mata Pelajaran disebut MGMP. MGMP merupakan wadah atau forum kegiatan pendidik mata pelajaran yang sejenis, mulai dari tingkat satuan pendidikan, kecamatan, kabupaten kota, tingkat provinsi, tingkat nasional dan regional. Semua itu, diadakan dan dilaksanakan sebagai upaya untuk mengembangkan kemampuan pedagogik digital pendidik dalam proses pembelajaran.

Berdasarkan observasi awal maka dilakukanlah penelitian yang berjudul "Peningkatan Kemampuan Pedagogik Digital Pendidik Melalui PDCA Dalam MGMP Masa Covid-19.

Berdasarkan latar belakang masalah diatas maka permasalahan pedagogik digital yang dilakukan oleh pendidik lima pelajaran di Satuan pendidikan berbagai macam dan tingkatan. Maka penelitian ini dibatasi pada bagaimana pelaksanaan pedagogik digital untuk pendidik lima mata pelajaran yang telah mengikuti kegiatan MGMP di SMP Negeri 91 Jakarta, yaitu berkaitan dengan: 1) Bagaimana pelaksanaan tindak lanjut pembelajaran tatap maya diiakukan oleh pendidik-pendidik sehingga dapat meningkatkan kemampuan dan kemampuan pendidik dalam pembelajaran secara digital di SMPN 91 Jakarta?; 2) Apakah dengan dilaksanakannya PJJ secara tatap maya oleh pendidik-pendidik melalui MGMP Satuan pendidikan dengan PDCA dapat meningkatkan kemampuan digital pembelajaran di SMPN 91 Jakarta?

Manfaat dari penelitian ini, diantaranya: 1) bagi pendidik, penelitian ini dapat memberikan motivasi pendidik meningkatkan kemapuan pedagogik; 2) bagi MGMP Kecamatan bisa memberikan informasi alat ukur keberhasilan yakni kekuatan dan kelemahan pelaksanaan program MGMP LMP (Lima Mata Pelajaran) secara tatap maya di satuan pendidikan; 3) bagi kepala satuan pendidikan, dapat menjadikan referensi dan informasi tentang pelaksanaan PJJ di satuan pendidikan dalam kegiatan MGMP. 
Penjelasan tentang kemampuan pedagogik terdapat dalam Peraturan Pemerintah Nomor 19 Tahun 2017 tentang SNP, merupakan kemampuan mengelola pembelajaran peserta didik yang meliputi pemahaman terhadap peserta didik, perancangan dan pelaksanaan pembelajaran, evaluasi pembelajaran, serta pengembangan peserta didik untuk mengaktualisasikan berbagai potensi yang dimilikinya (Siswoyo 2013).

Pedagogik selalu dua arah. Dalam pedagogik, terdapat hubungan yang tidak terpisahkan antara tenaga pendidik dan peserta didik. Tenaga pendidik dan peserta didik berinteraksi secara aktif dalam kegiatan mengajar dan belajar maka diperlukan kontekstualisasi sebagai pendekatan untuk pengajaran (O'Donald 2015).

Perencanaan untuk pembelajaran yang kontennya lebih sedikit daripada berbasis pemecahan masalah merupakan cakupan dari pedagogik digital. Pendekatan ini menyajikan aspek pengetahuan sebagai masalah dibanding sebagai perbaikan. Oleh karena itu dapat mempromosikan keterampilan berpikir tingkat tinggi dan peserta didik beralih dari mengingat konten kepada mendapatkan pemahaman konsep yang mendalam (Holdway 2014). Hal ini juga memungkinkan peserta didik mengembangkan analisis kritis, metakognisi dan refleksi, sering melalui pembuatan, pengeditan dan penerbitan online (Luckin 2014).

PDCA sebagai proses sesungguhnya tidak berakhir pada langkah Act, tetapi merupakan proses yang kontinyu dan berkesinambungan sehingga kembali lagi pada langkah pertama dan seterusnya (Gregorius 2018).

\section{METODE PENELITIAN}

Penelitian ini dilakukan di SMP Negeri 91 Jakarta Timur, yaitu pada semester genap Tahun Pelajaran 2020/2021. Penelitian dilaksanakan selama empat bulan dari tanggal 01 Januari 2021 - 19 April 2021. Subjek penelitian adalah pendidik lima mata pelajaran (LMP) SMP Negeri 91 Jakarta Timur yang menjadi anggota dari Sanggar MGMP pendidik di Kecamatan Pasar Rebo Jakarta Timur. Di SMP Negeri 91 Jakarta, seluruh pendidik pendidik lima mata pelajaran berjumlah 16 orang yakni pendidik kelompok mata pelajaran IPA, Matematika, IPS, Bahasa Indonesia, dan Bahasa Inggris. Metode penelitian yang digunakan PTS adalah tindakan cerdas yang dilakukan kepala satuan pendidikan dengan prinsip SMART, mengandung pengertian specific (khusus), managable (dapat dilaksanakan), acceptable (dapat dicapai), realistic (kegiatan nyata) dan time-bound (dalam batas tertentu) (Suharsimi 2011).

Tindakan tersebut diberikan oleh kepala satuan pendidikan selama tiga siklus tiga kali pertemuan tiap siklus dan 4 aktifitas. Instrumen yang digunakan berupa Instrumen angket untuk memperoleh data, dibuat dalam bentuk daftar pertanyaan secara tertulis yang diberikan kepada responden. Selanjutnya pengamat mencatat hal-hal penting yang ditemui selama observasi pada siklus 1, 2, dan 3.

Data yang diperoleh kemudian dianalisis dengan teknik deskripsi kualitatif beradasarkan permasalahan untuk menjadi sebuah laporan penelitian.

Hasil PTS ini dapat diketahui dari indikator kemampuan PGD (pedagogik digital) pendidik LMP dalam hal: a) sekurang-kurangnya 15 orang pendidik LMP memiliki administrasi kelas daring (pembelajaran) secara lengkap; b) sekurang-kurangnya 12 orang pendidik LMP mencapai target kurikulum 75\% dari 16 pendidik LMP selama masa dalam MGMP satuan pendidikan secara luring dengan protokol kesehatan; c) sekurang-kurangnya rata-rata $75 \%$ dari 16 orang pendidik LMP dapat mencapai ketuntasan belajar peserta didiknya.

\section{HASIL PENELITIAN DAN PEMBAHASAN}

Hasil observasi pada siklus 1 disajikan pada tabel berikut: 
Tabel 1. Hasil PGD Pendidik LMP Setelah Tindakan Siklus I

\begin{tabular}{|c|c|c|c|c|c|c|c|}
\hline \multirow{3}{*}{ No } & \multirow{3}{*}{ Aspek Yang Dinilai } & \multicolumn{5}{|c|}{ Nilai } & \multirow{3}{*}{$\begin{array}{l}- \text { Ket } \\
5\end{array}$} \\
\hline & & \multirow[t]{2}{*}{ Maks } & \multicolumn{4}{|c|}{ Perolehan } & \\
\hline & & & 1 & 2 & 3 & 4 & \\
\hline 1 & WAG & 3 & 3 & 3 & 3 & 3 & 2 \\
\hline 2 & Word & 3 & 3 & 3 & 3 & 2 & 3 \\
\hline 3 & Excel & 3 & 3 & 2 & 2 & 2 & 2 \\
\hline 4 & Bluetooth & 3 & 3 & 2 & 2 & 2 & 2 \\
\hline 5 & Zoom Meeting & 3 & 3 & 3 & 3 & 2 & 3 \\
\hline 6 & Padlet & 3 & 1 & 1 & 1 & 1 & 1 \\
\hline 7 & Video Level 1 & 3 & 2 & 2 & 2 & 2 & 2 \\
\hline 8 & Video Level 2 & 3 & 1 & 1 & 1 & 1 & 1 \\
\hline 9 & Video Level 3 & 3 & 1 & 1 & 1 & 1 & 1 \\
\hline 10 & Quizziz & 3 & 2 & 2 & 2 & 2 & 2 \\
\hline 11 & PPT & 3 & 3 & 3 & 3 & 3 & 3 \\
\hline 12 & Share PPT dalam zoom & 3 & 3 & 3 & 3 & 3 & 2 \\
\hline \multirow[t]{2}{*}{13} & Google Classroom & 3 & 2 & 1 & 1 & 1 & 1 \\
\hline & Jumlah (\%) & 100 & 77 & 69 & 69 & 67 & 6469 \\
\hline
\end{tabular}

Hasil pelaksanaan observasi tehadap PGD pendidik LMP, yang berada di kelas online terhadap pendidik-pendidik LMP yang tergabung dalam kelompok MGMP pendidik LMP berdasarkan tabel 1, dapat di ketahui bahwa: 1) pendidik dalam dalam mengajar sudah mulai komitmen pada RPP daring; 2) efisiensi waktu pada prosedur RPP online, banyak yang belum menguasai digital namun sudah memiliki agenda; 3) budaya pra test dilakukan dan pos test tidak dilakukan; 4) rata-rata hasil PGD 77\%>KKM 75\% (baik) pada kelompok 1 tapi masih ada 4 kelompok pendidik dibawah KKM 75\% (cukup) maka perlu bimbingan terpadu dan terarah.

Selanjutnya untuk observasi pada siklus 2, disajikan pada tabel berikut:

Tabel 2. Hasil PGD Pendidik LMP Setelah Tindakan Siklus II

\begin{tabular}{|c|c|c|c|c|c|c|c|c|}
\hline \multirow{3}{*}{ No } & \multirow{3}{*}{ Aspek Yang Dinilai } & \multicolumn{5}{|l|}{ Nilai } & \multirow{2}{*}{\multicolumn{2}{|c|}{ Ket }} \\
\hline & & \multirow[t]{2}{*}{ Maks } & \multicolumn{4}{|c|}{ Perolehan } & & \\
\hline & & & 1 & 2 & 3 & 4 & 5 & \\
\hline 1 & WAG & 3 & 3 & 3 & 3 & 3 & 3 & \\
\hline 2 & Word & 3 & 3 & 3 & 3 & 3 & 3 & \\
\hline 3 & Excel & 3 & 3 & 3 & 3 & 3 & 2 & \\
\hline 4 & Bluetooth & 3 & 3 & 3 & 2 & 3 & 3 & \\
\hline 5 & Zoom Meeting & 3 & 3 & 3 & 3 & 3 & 3 & \\
\hline 6 & Padllet & 3 & 2 & 2 & 2 & 2 & 2 & \\
\hline 7 & Vidio Level 1 & 3 & 3 & 3 & 3 & 3 & 3 & \\
\hline 8 & Vidio Level 2 & 3 & 2 & 2 & 2 & 2 & 2 & \\
\hline 9 & Vidio Level 3 & 3 & 1 & 1 & 2 & 1 & 1 & \\
\hline 10 & Quizziz & 3 & 2 & 2 & 2 & 2 & 2 & \\
\hline 11 & PPT & 3 & 3 & 3 & 3 & 3 & 3 & \\
\hline 12 & Share PPT dalam zoom & 3 & 3 & 3 & 3 & 3 & 2 & \\
\hline \multirow[t]{2}{*}{13} & Class Room & 3 & 3 & 2 & 2 & 2 & 2 & \\
\hline & Jumlah (\%) & 100 & 87 & 85 & 85 & 85 & 69 & 82 \\
\hline
\end{tabular}

Berdasarkan tabel 2 tersebut, dapatlah diketahui bahwa: 1) pendidik dalam dalam mengajar sudah komitmen dengan baik pada RPP daring; 2) efisien waktu pada prosedur RPP sudah sangat efektif secara online; 3) hanya pendidik kelompok 5 yang tidak/belum up to date; 4) budaya pre test dan pos test sudah dilakukan dengan optimal; 5) masih ada pendidik dengan kemampuan dibawah KKM; dan 6) rata-rata hasil PGD 85\%>KKM 75\% berarti ada kenaikan 16\% bila dibanding siklus I. 
Sementara untuk hasil observasi siklus 3 tersaji pada tabel berikut:

Tabel 3. Hasil PGD Pendidik LMP Setelah Tindakan Siklus III

\begin{tabular}{|c|c|c|c|c|c|c|c|c|}
\hline \multirow[t]{3}{*}{ No } & \multirow[t]{3}{*}{ Aspek Yang Dinilai } & & \multicolumn{4}{|c|}{ Nilai } & \multirow{2}{*}{\multicolumn{2}{|c|}{$\frac{\text { Ket }}{\text { Ket }}$}} \\
\hline & & \multicolumn{2}{|l|}{ Maks } & \multicolumn{3}{|c|}{ Perolehan } & & \\
\hline & & & 1 & 2 & 3 & 4 & 5 & \\
\hline & & & 1 & 2 & 3 & 4 & 5 & \\
\hline 1 & WAG & 3 & 3 & 3 & 3 & 3 & 3 & \\
\hline 2 & Word & 3 & 3 & 3 & 3 & 3 & 3 & \\
\hline 3 & Excel & 3 & 3 & 3 & 3 & 3 & 3 & \\
\hline 4 & Bluetooth & 3 & 3 & 3 & 2 & 3 & 3 & \\
\hline 5 & Zoom Meeting & 3 & 3 & 3 & 3 & 3 & 3 & \\
\hline 6 & Padllet & 3 & 3 & 2 & 2 & 2 & 2 & \\
\hline 7 & Vidio Level 1 & 3 & 3 & 3 & 3 & 3 & 3 & \\
\hline 8 & Vidio Level 2 & 3 & 3 & 3 & 2 & 2 & 2 & \\
\hline 9 & Vidio Level 3 & 3 & 2 & 3 & 2 & 2 & 2 & \\
\hline 10 & Quizziz & 3 & 2 & 2 & 2 & 2 & 2 & \\
\hline 11 & PPT & 3 & 3 & 3 & 3 & 3 & 3 & \\
\hline 12 & Share PPT dalam zoom & 3 & 3 & 3 & 3 & 3 & 2 & \\
\hline \multirow[t]{2}{*}{13} & Class Room & 3 & 3 & 3 & 3 & 3 & 3 & \\
\hline & Jumlah (\%) & 100 & 95 & 95 & 87 & 90 & 86 & 90 \\
\hline
\end{tabular}

Ket.Kolom perolehan No. 1- 5 adalah kelompok pendidik LMP Tabel 3

Berdasarkan tabel 3 tersebut, dapatlah diketahui bahwa: 1) pendidik dalam dalam mengajar sudah komitmen dengan baik pada rencana perbaikan pembelajaran daring; 2 ) efisien waktu pada prosedur RPP sangat efektif; 3) sudah tidak ada pendidik yang tidak mampu PGD; 4) budaya pre test dan pos test sudah dilakukan dengan maksimal; 5) semua pendidik-pendidik LMP dengan kemampuan PGD $>$ KKM, dan (6) rata-rata hasil PGD pendidik-pendidik LMP sebesar 91 (sangat baik) 90\%>KKM $75 \%$, terjadi kenaikan $8 \%$ bila dibandingkan dengan siklus II (82\%) dan jika banding dengan siklus I maka perbaikan dan meningkat 13\% berarti signifikan.

Berdasarkan observasi pada siklus 1, siklus 2 dan siklus 3, selanjutnya bisa dilihat komparasinya sebagai berikut:

Tabel 4. Hasil PGD Pendidik LMP antar Siklus I, Siklus II, dan Siklus III

\begin{tabular}{|c|c|c|c|c|c|}
\hline \multirow{3}{*}{ No. } & \multirow{3}{*}{$\begin{array}{c}\text { Kelompok-Mata } \\
\text { Pelajaran }\end{array}$} & \multicolumn{4}{|c|}{ NILAI } \\
\hline & & \multicolumn{3}{|c|}{ Siklus } & \multirow{2}{*}{ Kualitatif } \\
\hline & & I & II & III & \\
\hline 1. & IPA & 77 & 87 & 95 & $A$ \\
\hline 2. & Matematika & 69 & 85 & 95 & $A$ \\
\hline 3. & IPS & 69 & 85 & 87 & B \\
\hline 4. & B.Inggris & 69 & 85 & 90 & B \\
\hline \multirow[t]{3}{*}{5.} & B. Indonesia & 64 & 69 & 85 & B \\
\hline & Jumlah & 348 & 411 & 452 & $A$ \\
\hline & Rata-Rata & 70 & 82 & 90 & B \\
\hline
\end{tabular}

Hasil PGD pendidik LMP mulai dari siklus I hingga siklus III terjadi peningkatan yang signifikan terdapat 2 kelompok pendidik yang bernilai A dan 3 kelompok pendidik nilai B menunjukkan kemampuan pendidik baik bila ditinjau dari PGD pendidik LMP maka PGD sangat penting untuk meningkatkan kemampuan pedagogik digital pendidik dapat dianalisis dari siklus I dengan siklus II meningkat 2\%, siklus II dengan siklus III kenaikannya signifikan 8\% maka bila dibandingkan siklus III terhadap siklus I terdapat kenaikan signifikan 20\%>diatas KKM, rata-rata kualitatif B. Hal ini menunjukkan bahwa PGD secara terstruktur dapat meningkatkan kemampuan pendidik LMP. Meningkatkan kemampuan pendidik MGMP satuan pendidikan melalui PGD terstruktur dan paradigma pendidik tentang MGMP ditinjau hasil ulangan harian menunjukkan sinergi secara paralel meningkat signifikan dengan positif bila dilaksanakan secara terstruktur dan sistemik. 
Pelaksanaan MGMP tingkat satuan pendidikan, dilaksanakan setiap minggu pertama hari kamis setiap bulan selama satu semester yakni semester genap pada tahun pelajaran 2020/ 2021. Pelaksanaan MGMP tingkat Kecamatan, dilaksanakan minggu kedua hari kamis setiap bulan semester genap pada tahun pelajaran 2020/ 2021. Pelaksanaan MGMP tingkat Kotamadya, dilaksanakan pada setiap minggu ketiga hari kamis setiap bulannya semester genap pada tahun pelajaran 2020/2021. Pelaksanaan MGMP tingkat Provinsi DKI Jakarta, dilaksanakan hari kamis minggu keempat setiap bulan semester genap pada tahun pelajaran 2020/2021.

Sampai dengan saat ini ketuntasan belajar belum memuaskan dan kemampuan pendidik LMP belum memiliki kesamaan visi (pandangan) dan misi (target sasaran), terutama dalam proses pembelajaran. Oleh karena itu, maka kepala satuan pendidikan mengambil langkah sebagai berikut: 1) Kegiatan MGMP (sebagai eksperimen kualitatif); 2) Hasil kunjungan kelas online (sebagai kontrol); dan 3) Hasil belajar remedial dan tuntas merupakan dampak PDG.

Pra penelitian, mengumpulkan pendidik-pendidik LMP SMP Negeri 91 Jakarta sebanyak 16 orang dalam rangka kegiatan MGMP Satuan pendidikan. Kegiatan ini merupakan observasi awal untuk mengetahui keadaan yang sesungguhnya tentang paradigma dan sikap pendidik dalam kegiatan MGMP, dilaksanakan pada bulan Februari 2021.

Langkah-langkah yang akan dilaksanakan adalah: 1) mengidentifikasi masalah, berkaitan dengan program MGMP online, jadwal kegiatan online dan struktur pelaksanaan; 2) agenda lomba-lomba yang dilaksanakan pihak diluar dinas; 3) tindakan yang dilakukan adalah menentukan 3 kali pertemuan MGMP untuk menyamakan pembuatan peragaan Rancangan Pembelajaran (RP) daring kegiatan ini sebagai bentuk eksperimen; dan 4) membuat rancangan kesepakatan sebagai aplikasi pembuatan rancangan pembelajaran ke proses pembelajaran daring, ini merupakan kegiatan sebagai kontrol hasil PDG dalam MGMP.

Siklus pertama yaitu tahap perencanaan. Pada kegiatan ini akan didiskusikan dan dianalisis bersama pendidik-pendidik LMP dalam pertemuan MGMP terkait data wawancara, data angket, data PGD MGMP, dan jadwal online/kunjungan kelas.

Tahap pelaksanaan tindakan sebagai berikut: 1) melakukan wawancara dengan pendidik di kegiatan MGMP; 2) menerima hasil isian angket dari para peserta MGMP; 3) melakukan PDG MGMP dengan merekap kehadiran peserta, menganalisis masukan MGMP, dan mendata hasil pembuatan RPP daring; 4) mengikuti kegiatan MGMP minimal 6 kali kegiatan atau 6 minggu selama dua setengah semester di tahun pelajaran yang berjalan; dan 5) setelah memantau pelaksanaan MGMP dalam program pembuatan RPP daring bersama, maka dibahas jadwal PGD yang sudah disepakati.

Sebelum pelaksanaan MGMP akan dilaksanakan PGD kelas online 2 kali dan sesudah MGMP peneliti akan mengadakan kunjungan kelas online 2 kali. Tahap observasi, setelah serangkaian tindakan pada kegiatan siklus I dilaksanakan yaitu baik kegiatan PGD MGMP LMP dan kunjungan kelas online, maka hasil PGD kegiatan MGMP LMP, setelah didiskusikan bersama kelas daring, hasil pelaksanaan observasi PGD MGMP. Pelaksanaan PGD MGMP LMP untuk pendidik-pendidik di SMPN 91 Jakarta, sesuai dengan jadwal dan kesepakatan bersama antara kepala satuan pendidikan dan pendidikpendidik LMP tersebut, yang diawali dengan pemberian angket kepada pendidik-pendidik LMP.

Hasil angket presepsi dan motivasi untuk pendidik-pendidik LMP setelah tindakan terjadi perbaikan walaupun masih di bawah KKM 39\% yang memberikan tanggapan/jawaban ya dan jawaban tidak sebesar $61 \%$ dan didominasi oleh jawaban PGD ada dalam program MGMP sebesar 63\%. Berdasarkan data tersebut maka pendidik LMP sudah mulai ada perubahan memberi respon terhadap kegiatan MGMP. Berdasarkan angket perubahan paradigma pendidik secara umum pada siklus I setelah tindakan: 1) pendidik yang mengadakan MGMP dapat hadir 37\%; 2) pendidik memahami PGD 44\% dengan demikian paradigma masih dibawah KKM 75\%; 3) ada sebesar 31\% pendidik LMP yang merasakan manfaat MGMP terhadap profesinya; 4) sebesar $50 \%$ yang sudah memahami hari-hari pelaksanaan MGMP; dan 5) 31\% ketergantungan.

Hasil observasi PGD Pendidik LMP setelah tindakan siklus I, yang berada di satuan pendidikan terhadap pendidik-pendidik LMP yang tergabung dalam kelompok MGMP pendidik LMP, dapat di ketahui bahwa: 1) pendidik dalam mengajar sudah mulai komitmen pada RPP; 2) efisiensi waktu pada prosedur RPP. Banyak yang belum menguasai digital namun sudah memiliki agenda; 3 ) budaya pre 
test dilakukan dan pos test tidak dilakukan; dan 4) rata-rata hasil PGD 77\%>KKM 75\% (baik) pada kelompok 1 tapi masih ada 4 kelompok pendidik dibawah KKM 75\% (cukup) maka perlu bimbingan terpadu dan terarah.

Berdasarkan data evaluasi ulangan harian yang dilakukan tiap pendidik bidang studi LMP, ketika melakukan analisis data diperoleh dari setiap pendidik LMP saat melakukan MGMP satuan pendidikan. Pada kemampuan kedua semua pendidik-pendidik LMP melakukan ulangan harian pertama minggu ketiga Februari bahwa yang mengalami remedial 890 peserta didik $31 \%$ dari seluruh jumlah peserta didik 2880 peserta didik dan yang tuntas 1990 peserta didik $69 \%$ dari seluruh jumlah peserta didik 2880 peserta didik. Ini menunjukkan kemampuan pendidik-pendidik LMP pada siklus pertama bila ditilik dari hasil belajar peserta didik sangat rendah, yang mengalami remedial 890 peserta didik pada siklus pertama. Remedial dan tuntas KD pertama Siklus I, mengalami remedial. Bahwa yang mengalami ketuntasan hanya 5 pendidik dari 16 pendidik dan 2 kelompok mata pelajaran dari 5 kelompok mata pelajaran di atas KKM. 3 kelompok mata pelajaran dan 11 pendidik di bawah KKM jadi kualitas kemampuan pendidik LMP pada KD pertama sangat rendah sekali bila dilihat dari hasil ulangan harian, jadi kualitas kemampuan pendidik LMP pada KD pertama sangat rendah sekali bila dilihat dari hasil ulangan harian, maka beranjak ke siklus kedua.

Refleksi dari kegiatan tindakan satuan pendidikan, terhadap pelaksanaan MGMP pendidik LMP berdasarkan data hasil observasi, maka perlu dilakukan tindakan siklus II untuk memberikan atau mendorong perbaikan kemampuan PGD pada MGMP pendidik LMP di satuan pendidikan.

Siklus kedua tahap perencanaan. Pada kegiatan ini peneliti akan mendiskusikan bersama pendidik-pendidik LMP dalam pertemuan MGMP Satuan pendidikan, tahap-tahap perencanaan, sebagai berikut: 1) data wawancara siklus I sebagai pembanding terhadap siklus II; 2) data angket siklus I sebagai pembanding, dan angket siklus II; 3) data PGD MGMP siklus I pembanding, PGD siklus II; dan 4) jadwal PGD/kunjungan kelas online. Tahap pelaksanaan tindakan, langkah-langkah tindakan sebagai berikut: 1) melakukan wawancara dengan pendidik di kegiatan MGMP via online; 2) menerima hasil isian angkat dari para peserta MGMP via WAG; 3) melakukan PGD MGMP dengan merekap kehadiran peserta via WAG, menganalisis masukan MGMP, mendata hasil pembuatan RPP daring; 4 ) mengikuti kegiatan MGMP minimal 6 kali kegiatan atau 6 minggu selama satu semester di tahun pelajaran yang berjalan masa Covid-19; dan 5) setelah memantau pelaksanaan MGMP dalam program pembuatan RPP daring bersama, maka peneliti membahas jadwal PGD yang sudah disepakati sebelum pelaksanaan MGMP, peneliti melaksanakan PGD kelas 2 kali dan sesudah MGMP, peneliti akan mengadakan kunjungan kelas online 2 kali.

Tahap observasi, setelah serangkaian tindakan pada kegiatan siklus I dilaksanakan yaitu baik kegiatan PGD MGMP LMP dan kunjungan kelas online. Observasi PGD MGMP, pelaksanaan PGD MGMP LMP untuk pendidik-pendidik LMP, sesuai dengan jadwal dan kesepakatan bersama antara Kepala Satuan pendidikan dan pendidik LMP tersebut, diawali dengan pemberian angket kepada pendidik-pendidik LMP tersebut.

Hasil angket pendidik LMP setelah tindakan pada siklus 2, ternyata yang memberikan jawaban ya 47\% dan aspek nomor 5 (apakah ada PGD MGMP dari instasi terkait) 75\%>KKM, dan didominasi oleh jawaban aspek 1, 3, dan 8 dengan rata-rata 56\% sehingga paradigma dan perbaikan attitude pendidik LMP mencapai 56\% bila dibanding siklus I, 50\% berarti ada kenaikan 6\% hanya aspek 10 yang masih jalan ditempat sedangkan aspek 2, 4, dan 9 sudah mengalami jawaban yang sangat drastis walaupun masih dibawah KKM 75\%>50\%.

Berdasarkan angket tersebut, maka paradigma gambaran MGMP pendidik LMP, meningkat 8\%, tapi ada kelompok pendidik dengan kemampuan dibawah KKM, dan rata-rata hasil PGD 85\%>KKM 75\% berarti ada kenaikan 16\% bila dibanding siklus I.

Kemampuan pendidik dapat dianalisis berdasarkan hasil belajar ulangan harian seluruh peserta didik pada kemampuan dua, bulan Februari minggu ketiga, bahwa rata-rata semua peserta didik $86 \%>$ KKM bila dibanding siklus kedua $69 \%$ ada kenaikan $17 \%$ sudah berada diatas KKM. Maka berlanjut ke siklus ketiga karena pada hasil PGD masih belum maksimal penguasaan kemampuan PGD masih ada kelompok 5,69\% dibawah KKM dan persepsi dan motivasi masih 47\%<KKM, artinya masih ada perbaikan kemampuan pada minggu keempat Februari, maka berlanjut ke siklus ketiga. 
Refleksi dari kegiatan tindakan satuan pendidikan, terhadap pelaksanaan MGMP pendidik LMP di SMP Negeri 91 Jakarta, berdasarkan hasil observasi atau tindakan satuan pendidikan yang dilakukan, maka perlu dilakukan tindakan satuan pendidikan berupa PGD untuk memberikan atau mendorong perbaikan kemampuan PGD MGMP pendidik LMP di satuan pendidikan. Karena persepsi dan motivasi pendidik LMP 47\% dibawah KKM 75\% dan masih ada satu kelompok pendidik hasil PGD kurang kompeten sebesar 69\% dibawah KKM 75\% maka berlanjut ke siklus III.

Siklus ketiga tahap perencanaan. Pada kegiatan ini didiskusikan bersama pendidik-pendidik LMP, kolaborator dalam pertemuan MGMP satuan pendidikan, tahap-tahap perencanaan sebagai berikut: 1) data wawancara siklus II sebagai pembanding siklus III;2) data angket siklus II pembanding lembar angket siklus II; 3) data PGD MGMP siklus II pembanding, PGD siklus III;dan 4)jadwal PGD/kunjungan kelas online terstruktur dengan sistemik.

Tahap pelaksanaan tindakan siklus 3. Pelaksanaan tindakan satuan pendidikan dilakukan selama dua setengah bulan yaitu pada minggu pertama bulan Februari 2020 sampai dengan bulan April 2021, langkah-langkah tindakan sebagai berikut; 1) melakukan wawancara dengan pendidik LMP pada kegiatan PGD MGMP; 2) menerima hasil isian angket dari para peserta PGD MGMP; 3) mendiskusikan saling share dengan kolaborator, pendidik-pendidik LMP berdasarkan data akurat siklus II; 4) melakukan PGD MGMP yaitu : merekap kehadiran peserta, menanyakan masukan MGMP, menanyakan hasil pembuatan rencana perbaikan pembelajaran daring; 5) mengikuti kegiatan MGMP minimal 6 kali kegiatan atau 6 minggu selama satu semester di tahun pelajaran yang berjalan sesuai program; dan 6) setelah memantau peiaksanaan MGMP dalam program pembuatan perbaikan RPP daring bersama, maka dibahas jadwal PGD yang sudah disepakati sebelum pelaksanaan MGMP akan melaksanakan PGD kelas 3 kali dan sesudah MGMP akan mengadakan kunjungan kelas online 3 kali.

Tahap observasi, setelah serangkaian tindakan pada kegiatan siklus II dilaksanakan yaitu baik kegiatan PGD MGMP LMP dan kunjungan kelas online, hasil observasi PGD MGMP. Pelaksanaan PGD MGMP pendidik-pendidik LMP, sesuai dengan jadwal dan kesepakatan bersama antara kepala satuan pendidikan dan pendidik LMP tersebut, yang diawali dengan pemberian angket kepada pendidikpendidik LMP. Hasil angket pendidik LMP setelah tindakan pada siklus 3, ternyata yang memberikan jawaban ya $83 \%$ dan masih ada data $69 \%$ yakni aspek nomor 3 (apakah anda tahu hari-hari yang dipakai untuk MGMP), dan didominasi oleh jawaban aspek 4, 6, 8,dan 10 dengan rata-rata 88\% sehingga paradigma dan perbaikan attitude pendidik LMP mencapai $83 \%$ bila dibanding siklus II, $47 \%$ berarti ada kenaikan 36\% dan aspek 2 dan 9 dengan rata-rata 75\% jalan sudah mengalami perubahan yang signifikan walaupun sama dengan KKM 75\%.

Berdasarkan angket tersebut, maka paradigma gambaran MGMP pendidik LMP yaitu: mengalami peningkatan $36 \%$ dari siklus II ke siklus III maka terjadi perbaikan kemampuan, attitude, dan paradigma dari siklus I hingga siklus III sebesar 25\% maka; 1) pendidik yang mengadakan MGMP yang bisa hadir baru 88\%; 2) setelah hadir MGMP sudah tahu apa yang harus dilakukan dengan perubahan konsep yang sangat baik dan signifikan sebesar $81 \%$; 3) 75\% pendidik-pendidik MGMP LMP sudah tidak ketergantungan; 4) semua yang menyepakati agenda MGMP sebesar dan $81 \%$; dan 5) hari pelaksanaan kegiatan MGMP mencapai $69 \%<$ KKM.

Observasi PGD di Kelas. Untuk mengetahui bagaimana pelaksanaan PGD dari MGMP pendidik LMP, maka dilakukan observasi terarah, terpadu dan terbimbing hasilnya: 1) pendidik dalam dalam mengajar sudah komitmen dengan baik pada rencana perbaikan daring Pembelajaran; 2) efisien waktu pada prosedur RPP daring sudah sangat efektif; 3 ) sudah tidak ada pendidik yang tidak mampu PGD atau action dilapangan; 4) budaya pre test dan pos test sudah dilakukan dengan maksimal; dan 5) semua pendidik-pendidik LMP dengan kemampuan PGD>KKM, 6) rata-rata hasil PGD pendidikpendidik LMP sebesar 83 (baik)>KKM 75\%, terjadi kenaikan 36\% bila dibandingkan dengan siklus II dan jika banding dengan siklus I maka perbaikan dan meningkat $42 \%$ berarti signifikan. Siklus 3 KD III bahwa semua kelompok pendidik, kemampuannya berada diatas KKM bila ditinjau dari hasil belajar ulangan harian sehingga rata-rata seluruh peserta didik yang tuntas $89 \%$ dan dibawah bimbingan pendidik, kemampuannya 95\%.

Maka dikatakan tuntas dan berhasil walaupun masih ada satu pendidik dibawah KKM. Kemampuan pendidik ditinjau dari hasil belajar ulangan harian pada KD ketiga siklus III untuk Pendidik No. 1, 2, 3, dan 5 sudah diatas KKM hanya kelompok Pendidik nomor 5 yang masih dibawah KKM yakni $69<75$, 
sehingga analisis rata-rata nilai ulangan harian III yang tuntas adalah 89>75 (KKM), bila dibandingkan siklus pertama maka meningkat 20\% (signifikan) sehingga penelitian hanya 3 siklus.

Refleksi terhadap pelaksanaan MGMP pendidik LMP di SMP Negeri 91 Jakarta, berdasarkan hasil observasi dan tindakan satuan pendidikan yang dilakukan, maka; 1) MGMP pendidik LMP pelaksanaannya sudah sangat baik; 2) pendidik-pendidik LMP menyadari manfaat dari kegiatan musyawarah pendidik LMP, baik di tingkat satuan pendidikan atau di tingkat sanggar Kecamatan dan tingkat Provinsi DKI untuk melaksanakan diskusi, musyawarah dan pear teaching berkaitan dengan problematika yang muncul di kelas masing-masing terdeteksi dan teratasi dengan sangat baik; 3) adanya upaya koordinasi dan kerja sama yang intens menjadi lebih baik karena sesama pendidik saling memberikan informasi yang dibutuhkan dalam kegiatan pembelajaran; dan 4) atas dasar itulah, maka perlu dilakukan tindakan satuan pendidikan berupa PGD untuk memberikan atau mendorong perbaikan kemampuan PGD MGMP pendidik LMP di satuan pendidikan.

Kemampuan PGD pendidik sangat meningkat dengan diadakannya MGMP satuan pendidikan secara intens terpadu dan terbimbing dengan sistemik bila dibandingkan siklus I dengan siklus III mengalami peningkatan signifikan 13\%, hal ini menyatakan bahwa MGMP satuan pendidikan yang dijalankan sesuai prosedur dan mekanisme yang terstruktur, terprogram dan konsisten secara menyeluruh dapat meningkatkan kemampuan dan kemampuan pedagogik digital pendidik-pendidik LMP diatas KKM.

Bila kemampuan pendidik LMP ditinjau dari hasil belajar ulangan harian secara riil maka dapat dianalisis pada data sebelum tindakan peserta didik yang remedial sejumlah rata-rata $46 \%$, setelah tindakan siklus I berkurang 31\%, kemudian siklus II menjadi 14\%, serta siklus III menurun tajam menjadi $11 \%$ artinya yang mengalami ketuntasan $89 \%$ diatas KKM berarti kemampuan pendidik LMP ditinjau dari hasil ulangan harian mengalami peningkatan signifikan 20\% bila siklus III dibandingkan terhadap siklus I, seluruh peserta didik yang mengalami ketuntasan belajar mencapai $89 \%$ dengan peningkatan yang signifikan bila dibandingkan dengan sebelum tindakan naik $43 \%$ artinya bahwa kemampuan pendidik LMP meningkat secara tajam dan signifikan.

Tabel 5. Hasil PGD Pendidik LMP Sebelum Tindakan, Siklus I, Siklus II, dan Siklus II

\begin{tabular}{llccccc}
\hline & \multirow{3}{*}{ No. } & Kelompok & \multicolumn{5}{c}{ NILAI } \\
\cline { 3 - 6 } & Mata Pelajaran & Sebelum Tindakan & \multicolumn{4}{c}{ Siklus } \\
\cline { 3 - 6 } & & 51 & I & II & III & \\
\hline 1. & IPA & 23 & 69 & 85 & 95 & A \\
2. & Matematika & 15 & 69 & 85 & 87 & B \\
3. & IPS & 15 & 69 & 85 & 90 & B \\
4. & B.Inggris & 15 & 64 & 69 & 85 & B \\
5. & B. Indonesia & 128 & 348 & 411 & 452 & A \\
\hline & Jumlah & 26 & 70 & 82 & 90 & B \\
\hline & Rata-Rata & & & & & A
\end{tabular}

Hasil PGD Pendidik LMP mulai dari sebelum tindakan hingga siklus III terjadi peningkatan yang signifikan terdapat 2 kelompok pendidik yang bernilai A dan 3 kelompok pendidik nilai B menunjukkan kemampuan pendidik Baik bila ditinjau dari PGD pendidik LMP maka PGD sangat penting untuk meningkatkan kemampuan pedagogik digital pendidik dapat dianalisis dari sebelum tindakan dengan siklus I terjadi kenaikan 44\%, siklus I dengan siklus II meningkat $2 \%$, siklus II dengan siklus III kenaikannya signifikan 8\% maka bila dibandingkan siklus III terhadap siklus I terdapat kenaikan signifikan 20\% diatas KKM, rata-rata kualitatif B. Hal ini menunjukkan bahwa PGD secara terstruktur dapat meningkatkan kemampuan pendidik LMP. Meningkatkan kemampuan pendidik MGMP satuan pendidikan melalui PGD terstruktur dan paradigma pendidik tentang MGMP ditinjau hasil ulangan harian menunjukkan sinergi secara paralel meningkat signifikan dengan positif bila dilaksanakan secara terstruktur dan sistemik.

Hasil yang demikian karena dilakukan secara sistemik, kolaboratif, dan terpadu dalam PGD selain bimbingan terarah juga terjadi antar interaksi kelompok LMP dengan tutorial sebaya dalam pengalihan kemampuan pedagogik digital melalui implementasi PDCA. 
Dalam penelitian (Riyantini 2017), pendekatan PDCA dapat meningkatkan efektifitas pelaksanaan kegiatan pemantauan dalam pengendalian mutu lembaga kursus dan pelatihan sedangkan dalam penelitian ini menunjukkan bahwa PDG pendidik LMP MGMP satuan pendidikan melalui strategi $P D C A$, dapat meningkatkan kemampuan pendidik. Jadi pada penelitian yang relevan meningkatkan efektifitas pelaksanaan pengendalian mutu dan pembanding pada penelitian meningkatkan kemampuan pendidik.

\section{SIMPULAN DAN SARAN}

Berdasarkan penelitian tindakan satuan pendidikan disimpulkan: 1) kemampuan pedagogik digital pendidik sangat meningkat dengan diadakannya MGMP Satuan pendidikan secara intens terpadu dan terbimbing dengan sistemik bila dibandingkan siklus I dengan siklus III mengalami peningkatan signifikan 44\%; 2) hasil PGD Pendidik LMP bila dibandingkan siklus III terhadap siklus I terdapat kenaikan yang signifikan yakni $20 \%$ diatas KKM dengan kualitatif B; dan 3) kemampuan pedagogik pendidik LMP ditinjau dari hasil belajar ulangan harian secara riil maka mengalami peningkatan signifikan $20 \%$ bila siklus III dibandingkan terhadap siklus I.

Berdasarkan hasil penellitian, disarankan yaitu: 1) untuk pendidik, pelaksanaan MGMP IPA terpadu dan terbimbing memiliki dampak terhadap kemampuan pedagogik digital pendidik LMP SMP Negeri 91 Jakarta, sehingga perlu optimalisasi pelaksanaan MGMP satuan pendidikan untuk meningkatkan kemampuan PGD pendidik; 2) untuk satuan pendidikan, PGD terstruktur oleh kepala satuan pendidikan berdampak terhadap kemampuan PGD pendidik di satuan pendidikan, sehingga kepala satuan pendidikan melalui satuan pendidikan, agar lebih meningkatkan PGD secara terbimbing untuk mewujudkan kemampuan pendidik yang lebih baik; dan 3) untuk peserta didik, senantiasa membangun self-esteem high confidence yang positif akibatnya hasil belajar peserta didik meningkat seiring kemampuan pendidik meningkat masa Covid-19.

\section{PUSTAKA ACUAN}

Arikunto, Suharsimi. "Penelitian Tindakan." In Penelitian Tindakan, by Suharsimi Arikunto, 4. Jogjakarta: Aditya Media, 2011.

Arikunto, Suharsimi. "Prosedur Penelitian." In Prosedur Penelitian, by Prosedur Penelitian, 11. Jakarta: Rineke Cipta, 2011.

Crowford. "Covid-19." In Covid-19, by Covid-19, 20. https: https://doi.org/10.37074/jalt.2020.3.1.7, 2020.

Gregorius, Hendra Poerwanto. “Model ISO 9001." In Model ISO 9001, by Hendra Poerwanto Gregorius, 3. Jakarta: https://sites.google. com/site/kelolakualitas/PDCA, 2018.

Holdway, Kent and. "Digital Pedagogy." In Digital Pedagogy, by Digital Pedagogy, 22. https: https, 2014.

Hussin, Shahroom \&. "Industrial Revolution 4.0 and Education." In Industrial Revolution 4.0 and Education, by Industrial Revolution 4.0 and Education, 3. International Journal of Academic Research: International, 2018.

Luckin. "Metacognisi." In Metacognisi, by Metacognisi, 12. https: https, 204.

Ng.W. "New Digital Technology in Education." In New Digital Technology in Education, by New Digital Technology in Education, 17. https: Springer International, 2017

O'Donald, S. "The Kntiivism Club." In The Kntiivism Club, by S. O'Donald, 36. Routledge: https://doi.org/10.4324/9780203863688.ch36., 2015.

R.Sebayang. "WHO Corona Darurat Global." In WHO Corona Darurat Global, by WHO Corona Darurat Global, 2. CNBC Indonesia: unduh, 2020.

Riyantini. "Jurnal IImiah VISI PGTK PAUD dan DIKMAS - Vol. 12, No. 2, Desember 2017." In VISI PGTK PAUD dan DIKMAS - Vol. 12, No. 2, by Jurnal IImiah, 1. Bandung: Duinas Pendidikan Bandung, 2017.

Siswoyo, Dwi. "Ilmu Pendidikan." In IImu Pendidikan, by Dwi Siswoyo, 120. Yogjakarta: UNY Press, 2013.

Strijbos. "Digital 4.0." https, 2015. 